\title{
RECENT PUBLICATIONS IN SCOTTISH \\ GOVERNMENT AND POLITICS
}

\section{H ALLEN}

The list below covers material omitted from previous listings, and material published since the last list, in the period 1.6.84 to 31.5.85. Where a publisher is not specified, the publisher and author are the same. I would be grateful to be told of any errors or omissions.

To make it easier to obtain theses on inter-library loan, I have included where possible the British Library (Lending Division) or University Microfilm numbers; these should be quoted when applying for a loan copy.

Two changes have been made in coverage. As there now exists a current index to the Scotsman (contact John Bennett, Scotsman Index Project, 21 Buccleuch Place, Edinburgh), I no longer cite newspaper feature articles in the index. I also do not list reports of investigations by the local Government Ombudsman.

1. ADAMS, I H, "One hundred years later: does Scotland exist?", Scottish Geographical Magazine, 100, 2 (1984), 123-34

2. AGNEW, J, The Geography of Scottish nationalism. Syracuse: Syracuse University Dept. of Geography, 1982, 24pp

3. ALEXANDER, D (ed.), Housing in Scotland: some current issues Stirling; Stirling University Dept. of Housing Administration, Occasional paper 2, 1984, 45pp

4. ... "Public sector housing in Scotland", Scottish Government Yearbook 1985, 152-70

5. ALEXANDER, $\mathbf{K}$, Rural renewal experience in the Highlands and Islands. Cambridge: Cambridge University Dept. of Land Economy, 1985, 26pp

6. ALLEN, C H, "Recent publications in Scottish government and politics", Scottish Government Yearbook 1985, 329-51

7. ALTERNATIVE EMPLOYMENT GROUP IN SCOTLAND, Unemployment strategies: a search for a new way forward. Edinburgh : SCCVO, 1984, 61pp

8. ANON, "Changes in regional policy", Scottish Economic Bulletin 30 (1984) $10-12$

9. ANON, "Glasgow's model future", Architects Journal, 21.11.84 
43-64

10. ARMSTRONG, A M \& MATHER, A.S., Land ownership and land use in the Scottish Highlands. Aberdeen: Aberdeen University Dept. of Geography, 1983, 158pp

11. ARMSTRONG, N, "The promotion of owner-occupation by Scottish public housing agencies", Housing in Scotland, ed. D Alexander

12. ASHCROFT, B K, "The new regional policy and the Scottish economy", Quarterly Economic Commentary, 10, 3 (1985) 75-79

13. ASSOCIATION OF SCOTTISH LOCAL HEALTH COUNCILS, LHC Review, Edinburgh, 1982, 28pp

14. BAILEY, S, Analysis of local authority income and expenditure: Glasgow connurbation. Glasgow: Glasgow University Dept. of Social and Economic Research (Inner City in Context, Clydeside Case Study, Working paper 3), 1984

15. BAIN, A D \& REID, G C, "The finance sector", Industry, policy and the Scottish economy, ed. Hood, N \& Young, S, 365-89

16. BAVISKAR, B S et al., Development institutions and approaches in three rural areas... Western Isles and the Grampian Region. Arkleton Trust, 1984, 104pp

17. BAXTER, L, "The political economy of Scotch whisky", Scottish Government Yearbook 1985, 77-106

18. BELL, D, "Trends in Scottish industry", Industry, policy and the Scottish economy, ed. Hood, N \& Young, S, 1-27

19. BLACK, J M, Provision for the single homeless in Glasgow. M.Litt thesis, Glasgow University, 1982

20. BLACKADDER, A, The impact of oil on the Shetland economy and strategy for the future. 17th annual conference of the Atlantic Association of Sociologists and Anthropologists, Nova Scotia, 1982

21. BLOW, S, "New face for Glasgow", Spectator, 14.7.84, 17-19

22. BOCHEL, J \& DENVER, D, "The 1984 European elections in Scotland", Scottish Government Yearbook 1985, 18-22

23. .... "The District elections of 1984", Scottish Government Yearbook $1985,5-17$

24. ... The Scottish District elections 1984: results and statistics. Dundee: University of Dundee Dept. of Political Science, 1984, $101 \mathrm{pp}$

25. BORDERS REGIONAL COUNCIL, Borders Region economic development annual report 1984. Newton St Boswells, 1985

26 .... Financial report and accounts 1983-84. Newton St Boswells, 1984, $48 \mathrm{pp}$

27. BRAILEY, M, "A woman's place is in the home", Roof, Sept/Oct 1984, 18-21
28. BRAND, J, National consciousness and voting in Scotland. Glasgow: Strathclyde University Dept. of Politics (Papers in Government and Politics 15), 1983

29. .... "Nationalism and the non-colonial periphery: Scotland and Catalonia", New nationalisms of the developed West, ed. Tiryakian, E A \& Rogowski, R, 277-93

30. BRAND, J \& JORDAN, M, Political parties and referendum. Duke University seminar paper, 1981

31. BRAND, J \& MILLER, W, The Labour Party in Scotland in 1979 Glasgow: Strathclyde University Dept. of Politics (Papers in Government and Politics 4), 1983, 24pp

32. BRAND, J. MILLER, W \& JORDAN, M, National consciousness and voting in Scotland. Paper given to Political Science Association conference 1981

33. BREMNER, J W \& MIDWINTER, A, Scottish local government finance: a guide to principles and practice. Dartford: Certified Accountant (Publications) Ltd., 1984, 30pp

34. BRIERLEY, P, \& MACDONALD, F (eds), Prospects for Scotland: report of the census of the churches in 1984. Bromley: MARC Europe \& National Bible Society of Scotland, 1985, 105pp

35. BRUCE, M, No Pope of Rome: militant protestantism in modern Scotland. Edinburgh: Mainstream, 1985, 270pp

36. BRYAN, G, Scottish nationalism and cultural identity in the twentieth century: an annotated bibliography of secondary sources. Westport: Greenwood, 1984, 180pp

37. BUCHAN, J M, Approaches and attitudes of managers to collective bargaining in North East Scotland. Ph.D. thesis, CNAA (Robert Gordons Institute), 1984, 436pp (BLLD No. : D52556/84)

38. BURTON, T, Business involvement in local plans: report to the SDD. Edinburgh, 1985, 45pp

39. BUTT, J, "The changing character of urban employment 1902-81", Perspectives of the Scottish city, ed. G Gordon, 212-35

40. BYRON, R, "Oil and changing concepts of community in Burra",

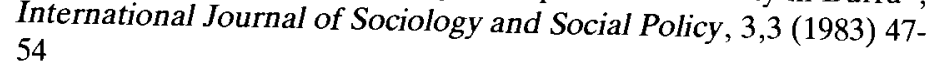

41. CAMPAIGN FOR A SCOTTISH ASSEMBLY, Blueprint for Scotland. Glasgow, n.d., 8pp

42. The Scottish constitutional convention. Glasgow, n.d. (1984), 8pp

43. CAMPBELL, D, "The real crisis of Scottish agriculture", Scottish Government Yearbook 1985, 107-33

44. CARTER, T, A member's introduction to local government finance. Aberdeen: Grampian Region Council, 1984, 14pp

45. C.E.S., Outer estates in Britain, interim report: preliminary 
comparison of four outer estates. London: CES Ltd, 1984, 44pp

46. CENTRE FOR URBAN AND REGIONAL RESEARCH, Rent schemes in British public housing: proceedings of a public policy seminar. Glasgow: Glasgow University C.U.R.R., 1984, 47pp

47. CHAPMAN, A D, Patterns of occupational mobility amongst men and women in Scotland 1930-70. Ph.D. thesis, CNAA (Plymouth Poly.) 1984, 322pp (BLLD No.:D53237/85)

48. CHRICHTON, D, "The textile and clothing sectors", Industry, policy and the Scottish economy, ed. Hood, N \& Young, S, 213-48

49. CITY OF ABERDEEN DISTRICT COUNCIL, Financial statement for the year ended 31 March 1984. Aberdeen, 1984, 35pp

50. CITY OF EDINBURGH DISTRICT COUNCIL, Financial report and abstract of accounts 1983-4, Edinburgh, 1984, 40pp

51. CLAPHAM, D F \& MALCOLM, J F (eds), Corporate planning in local authorities: two case studies. Glasgow: Glasgow University Centre for Urban and Regional Research, Discussion paper 15, $1984,47 \mathrm{pp}$

52. CLARKE T F, Producer cooperatives in market systems: a case study of the Scottish Daily News. Ph.D. thesis, Warwick University, 1983, 982pp (BLLD No.: D54896/85)

53. CLYDESDALE DISTRICT COUNCIL, Housing plan 5, 1985-90. Lanark, 1985, 21pp

54. COLWELL, R, "Regenerating run-down Glasgow", Public Finance and Accountancy, June 1985, 16-18

55. COMMISSIONER FOR LOCAL AUTHORITY ACCOUNTS IN SCOTLAND, Ninth Report and accounts. Edinburgh, 1984, 60p

56. COMMITTEE ON SCOTTISH AFFAIRS, Highlands and Islands Development Board, Second report from the Scottish Affairs Committee, Vol.I: Report and proceedings: Vol. II: Minutes of evidence. London: House of Commons Paper 22, 1985, 96pp and $410 \mathrm{pp}$

57. COMPTROLLER AND AUDITOR GENERAL, Appropriation accoaunts 1983/4. Vol. 10 - Class IV: Scotland. London: House of Commons Paper 614-X, 1984, 73pp

58. Investment accounts of the SDA, WDA and HIDB. London: House of Commons paper 230, 1985, 25pp

59. CONFEDERATION OF BRITISH INDUSTRY (SCOTLAND) Rate watching, A CBI guide to business/local authority consultation in Scotland. Glasgow, 1985, 41pp

60. COON, A G, An analysis of the specification of policies in structure plans. Glasgow: Glasgow School of Art Dept. of Planning, Occasional paper 8, 1984, 36pp

61. COOPER, J E B, "The oil industry in Scotland", Scottish Bankers
Magazine, No. 1984, 85-92

62. CRAIG, F W S, City and Royal Burgh of Glasgow: municipal election results 1948-73, Chichester: Parliamentary Research Services, 1984, 86pp

63. CRAWFORD, R M, The SNP 1960-74: organisation and power structure. Ph.D. thesis, Glasgow University, 1982.

64. CUNNINGHAM, C, "The SDP in Scotland", Radical Scotland 11 (1984) 14-15

65. DALTON, G E, "Crofting in the Western Isles: some economic aspects of its agriculture", Farm Management Review 17 (1982) 4148

66. DAWSON, A H, "Local government and the idea of the region: a comment on the present situation in Scotland", Scottish Geographical Magazine, 100, 2 (1984), 113-22

67. DEWHURST, J H L et al., The measurement of output and employment in the Scottish service sector (1962-80). Edinburgh: IDS (ESU research paper 7), 1984, 204pp

68. DONALDSON, R, "No women in the kitchen", Scottish Marxist 29 (1984) 3-5

69. DONNISON, D, "What can we learn from GEAR?", The Planner $71(1985)$ 53-54

70. DONNISON, D et al, "GEAR", The Planner 71 (1985) 8-12

71. DOUGLAS, G, Rural decline, a vicious spiral. A scheme for rural development in Scotland. Edinburgh: Rural Forum, 1984, 10pp

72. DOWNIE, A, The Garnock Valley community project: final report. Edinburgh: SCCVO, 1984, 37pp

73. DUGUID, G \& GRANT, R, Areas of special need in Scotland. Edinburgh: Scottish Office CRU, 1984, 21pp

74. DUMBARTON DISTRICT COUNCIL, Housing plan 1984-89. Dumbarton, 1983, 89pp

75. DUMFRIES \& GALLOWAY REGIONAL COUNCIL, Abstract of accounts for year ended 31 March 1984. Dumfries, 1984, 121pp

76. .... Annual report 1983-4. Dumfries, 1984, 48pp

77. .... Transport policies and programme 1983-89. Dumfries, 1983, $79 \mathrm{pp}$

78. EAST LOTHIAN DISTRICT COUNCIL, Housing plan 1985-90. Haddington, 1984, 63pp

79. EDINBURGH DISTRICT COUNCIL LABOUR GROUP Edinburgh: a socialist strategy. Edinburgh, 1984, 13pp

80. EDWARDS, R, "Scot Nats move left", New Statesman, 21.9.84, 13-14

81. "Waiting for the avalanche", New Statesman, 4.1.85, 11- 12

82. EHRENREICH, J $\mathbf{H}$, "Socialism, nationalism and capitalist 
development", Review of Radical Political Economics, 15, 1 (1983) $1-40$

83. ELDER, F M, Their rightful place: the role of women in the Church of Scotland. M.A. dissertation, Edinburgh University Dept. of Politics, 1985, 57pp

84. ENGLISH, J (ed), Public sector housing in Scotland. Stirling: Stirling University Dept. of Housing Administration, Occasional paper 1, 1983

85. EVANS, K, A discussion on the sale of council houses with particular reference to Edinburgh. M.A. dissertation, Edinburgh University Dept. of Politics, 1985, 77+19pp

86. FAIRLEY, J, "Towards a Scottish labour market board?", Radical Scotland, 12, (1984), 12-13

87. FALKIRK DISTRICT COUNCIL, Annual report and financial statement 1983-4. Falkirk, 1984, 39pp

87a. .... Housing plan 1985-90. Falkirk, 1984, 38pp

88. FAROUAR, W, "Reorganisation in Scotland: the end of the beginning?" Hospital and Health Services Review, 80, 1 (1984) 2021

89. FERGUSON, K, An introduction to local government in Scotland. Glasgow: Planning Exchange, 1984, 180pp

90. FIFE REGION COUNCIL, Annual report and financial statement 1983-84. Glenrothes, $1984,49 \mathrm{pp}$

91. ... Capital budget 1985-96 and capital financial plan 1985-90. Glenrothes, $1985,75 \mathrm{pp}$

92. .... Fife Region housing review 1984. Glenrothes, 1985

93. .... Revenue policy budget $1985 / 86$. Glenrothes, $1985,86 \mathrm{pp}$

94. .... Strategic projections 1983. Glenrothes, 1983, 114pp

95. FINANCIAL TIMES, "Scotland", Financial Times, 17.12.84, 9-12

96. FIRN, J R \& ROBERTS, D, "High-technology industries", Industry, policy and the Scottish economy, ed. Hood, $\mathrm{N} \&$ Young, $\mathrm{S}$, 288-325

97. FORBES, J, "A view of planing in Scotland", Scottish Geographical Magazine. 100, 2 (1984), 104-112

98. FREEMAN, I L, Views on social security: an examination of public attitudes to social security in the West of Scotland and social security legislation. Ph.D. thesis, Stirling University, 1983, 368pp (BLLD No.: D52099/84)

99. FURNISS, N, "Devolution and identity in Scotland and Wales", Dilemmas of change in British politics, ed. D T Studlar \& J L Waltman (London: Macmillan, 1984)

100. GARDNER, B, An analysis of the Scottish labour market during the 1970's. M.Litt. thesis, Aberdeen University, 1981
101. GLASGOW DISTRICT COUNCIL, Glasgow annual housing review. Glasgow, 1983, 382pp

102. .... District profile: facts and figures about Glasgow 1984. Glasgow, 1984

103. .... Economic development plan 4. Glasgow, 1984, 54pp

104. .... Housing plan 7. Glasgow, 1983, 193pp

105. .... Unemployment in Glasgow by local area: Jan. 1984. Glasgow, s $1984,22 \mathrm{pp}$

106. GOLD, J R \& GOLD, M M, Rural development in the Highlands and Islands of Scotland: a bibliography. Vance Bibliographies, 1982, $28 \mathrm{pp}$

107. GORDON, G (ed), Perspectives of the Scottish city. Aberdeen: Aberdeen University Press, 1985, 314pp

108. GORDON, I.C, The cyclical interation between regional migration, employment and unemployment: a time series analysis for Scotland. Canterbury: University of Kent Urban and Regional Studies Unit, $1984,39 \mathrm{pp}$

109. GRAHAM, S M, Decentralisation as a method of control in Scottish education 1955-65. M.Ed. dissertation, Edinburgh University, 1982

110. GRAMPIAN REGION COUNCIL, Annual report and accounts 1983-84. Aberdeen, 1984, 42pp

1il. ... Grampian strategic forecasts 1984 update: employment, population, housing. Aberdeen, 1984, 38pp

112. .... Transport policies and programme 1985-90. Aberdeen, 1985

113. .... Travelling people in Grampian Region. Aberdeen: GRC Social Work Dept., 1985, 139pp

114. GRAY, A M \& HUNTER, D J, "Priorities and resource allocation in the Scottish health services: some problems in 'planning and implementation"', Policy \& Politics, 11, 4 (1983) 417-37

115. GREGORY, P D, Factors influencing the export performance of the Scottish manufacturing sector of the offshore supplies industry. Ph.D. thesis, Edinburgh, 1982 (BLLD N.: D42878/82)

116. GRIGOR, I K, Local authority accommodation of oil-related developments in Easter Ross. Ph.D., thesis, Edinburgh University, 1985

117. GULLIVER, S, "The area projects of the SDA", Town Planning Review 55, 3 (1984), 322-34

118. HAGUE, C, The development of planning thought: a critical perspective. London: Hutchinson, 1984, 349pp

119. HAMILTON, R T, Measures and determinants of entry and exit rates of business in Scotland. Ph.D. thesis, London (External), 1982

120. HARGRAVE, A, Silicon Glen: reality or illusion? A global view of high technology in Scotland. Edinburgh: Mainstream, 1985, 128pp 
121. HARRIS, T et al., "The management of change: oil and the decline of local economic autonomy in Aberdeen", Radical Scotland 12, (1984), 20-21

122. The management of change: local government and oil in Aberdeen part I: a theoretical framework. Aberdeen: Aberdeen Univeresity Dept. of Political Economy, Discussion paper 84-02, 1984, 50pp

123. HARRISON, D, "The need for Leyland, Bathgate", Scottish Trade Union Review 24, (1984), 4-6

124. HART, F, "Local government in Scotland", Scottish Marxist 29 , (1984), 8-9

125. HASHAGAN, S, "Making and breaking the rules: a case study of local authority control in relation to tenant interests", Strathclyde Studies in Community Work, Vol. 2, ed. A Barr (Glasgow: Council of Voluntary Service, 1983), 5-23

126. HAUG, P, "Regional policy incentives in the Scottish electronics industry: survey evidence", Scottish Journal of Political Economy, 31, 3 (1984), 274-83

127. HAYTON, K, "Employment creation in deprived areas: the local authority role in promoting community business", Local Goverenment Studies, 9,6 (1983), 39-55

128. .... "Strathclyde's policy" (on economic initiatives), Local Government Policy Making, Nov. 1984, 51-55

129. .... "The Greater Easterhouse project", Initiatives, 2,3 (1985) 25-26

130. HECHTER, M, "Le colonialisme interne 'revue et corrige"", Pluriel 32 (1982), 119-28

131. HENDERSON D $M$, "The natural resource-based sector", Industry, policy and the Scottish economy, ed. Hood, N \& Young, S, 249-78

132 HENDERSON, D S, "Input-output tables for Scotland for 1979 : initial results", Scottish Economic Bulletin 29 (1984), 11-25

133. Scottish input-output tables for 1979. 5 vols. Edinburgh: Industry Dept. for Scotland, 1984-85. Individual volume titles:

I: Introduction and summary tables. 1984, 32pp

II: Detailed tables. 1984, 125pp

III: Further results and analyses. 1984, 199pp

IV: Sources and methods. 1984, 167pp

V: Comparisons with Scotland 1973 and UK 1979. 1985,114pp

134. HENDERSON, R A, "The employment performance of established manufacturing industry in the Scottish New Towns", Urban Studies, 21, 3 (1984) 295-315

135. HENRY, D (ed), Women and planning in Scotland. Glasgow: Strathclyde University Dept. of Urban and Regional Planning, 1985, $57 \mathrm{pp}$
136. HIGGS, L, New Town: social involvement in Livingston. Glasgow: Embryo Books, 1977, 248pp

137. HIGHLANDS AND ISLANDS DEVELOPMENT BOARD, Accounts 1983-84. London: House of Commons paper 30, 1984 $18 \mathrm{pp}$

138. .... Annual Report 19. Inverness, 1985, 71pp

139. .... The Board's strategy. Inverness, n.d., 21pp

140. .... The HIDB and its work: a reading list. Inverness, $1984,4 \mathrm{pp}$

141. HILL, A \& JACKSON, A A, "Breaking barriers", Scottish Marxist, 29 (1984), 6-7

142. HIMSWORTH, C, "The Lands Tribunal for Scotland and the government of council house sales", Urban Law and Policy, 6 (1984) 253-78

143. HOGAN, J \& AL-QADDO, H M, "Policy succession in a Scottish quango: the SSHA 1937-84", Scottish Government Yearbook 1985 $171-86$

144. HOOD, C, "From growth to retrenchment? A perspective on the growth of the Scottish Office to the 1980's", Scottish Government Yearbook 1985, 53-76

145. HOOD, C \& DUNSIRE, A, Bureaumetrics. Farnborough: Gower, 1981: see pp 209-32

146. HOOD, N, "The small firm sector", Industry, policy and the Scottish economy, ed. Hood, N \& Young, S, 57-92

147. HOOD, N \& YOUNG, S (eds), Industry, policy and the Scottish economy. Edinburgh: Edinburgh University Press, 1984, 421pp

148. .... Inward investment in Lanarkshire: an examination of the role of LIFE. Glasgow: Strathclyde University International Business Unit, 1984, 31pp

149. HOUSING CORPORATION, Housing associations and Glasgow: neighbourhood renewal and specialist housing. N. p., 1984, 6pp

150. HOWSON, A, Government civil research and development expenditure in Scotland. Edinburgh: Industry Dept. for Scotland (ESU Discussion paper 17), 1984, 19pp

151. HUNTER, D, "The lure of the organisational fix; reorganising the Scottish health service", Scottish Government Yearbook 1985, 23057

152. HUTCHINSON, J S, Oil, planning and housing in Aberdeen. M.Phil. thesis, Edinburgh, 1982

153. HUTTON, N, Lay participation in a public local inquiry. Ph.D. thesis, Edinburgh University, 1983, 300pp (BLLD No.: D53583/85)

154. INDUSTRY DEPARTMENT FOR SCOTLAND, Index of industrial production and construction for Scotland 1954-83. Edinburgh: IDS (Statistical Bulletin D1.1), 1985, 17pp 


\section{Scottish Government Yearbook 1986}

155. Overseas-owned firms in Scottish manufacturing industry in 1981 Edinburgh: SDD (Statistical Bulletin A2.1), 1984, 10pp

156. Recent trends in Scottish employment. Edinburgh: IDS (Statistical Bulletin G1.1), 1984, 7pp

157. Report of the working party on the transfer of housing in Scottish New Towns. Edinburgh, 1984, 57pp

158. JOLLIFFE, C, Bending mainline programmes: the utilisation of main programmes for urban regeneration. Glasgow: Glasgow University Dept. of Social and Economic Research (Inner City in Context, Clydeside Case Study, Working paper 8), 1984, 93pp

159. JONES, C, "Housing support grant in Scotland: the first five years", Public sector housing in Scotland, ed. J English, 44-57

160. JONES, H; CARD, J \& FORD, N, "A house in the Highlands", Town \& Country Planning, Nov. 1984, 326-7

161. .... "Counter-urbanisation in societal context: long-distance migration to the Highlands and Islands of Scotland", Professional Geographer, 36, 4 (1984) 437-44

162. JORDAN, G, The limits of planning: the Moray Firth Working Party and multi-organisational coordination. London: ESRC (North Sea Oil Panel Occasional paper 17), 1984, 92pp

163. KEATING, M, "After the party pieces...", Municipal Journal, $24.8 .84,1325-6$

164. Is there an urban policy in Scotland?. Paper given to Political Studies Association Workgroup on UK Politics, 1984, 20pp

165. .... "Local government spending and central control", Quarterly Economic Commentary, 10,4 (1985) 69-73

166. .... Peripheral nationalism and state policy in France and Britain. Paper given to European Consortium for Political Research Join Sessions of Workshops, Barcelona, 1985, 31pp

167. .... "Scotland in the European Communities", Regions in the European Communities. ed. M KEATING \& J B JONES (Oxford: Oxford University Press, 1984)

168. .... "Scots experience of urban decline and economic deprivation", Municipal Journal, 27.7.84, 1160-61

169. "Stands the Scottish Office where it did?", MOST, May 1984

170. KEATING, M \& BOYLE, $R$, "New Towns decision could end an era for regional development", Municipal Journal, 4.1.85, 8-9

171. KEATING, M \& GILCHRIST, J, "Scottish politics", Modern Studies Association Yearbook 1984, 52-57

172. KELLAS, J G, The Scottish political system. Third, revised edition. Cambridge: Cambridge University Press, 1984

172a KEREVAN, G, "The other TUC", Radical Scotland 11 (1984) 7-9

173. KEREVAN, G \& SAVILLE, R, "The case for Scottish coal",
Scottish Trade Union Review 26 (1985) 6-8

174. .... The case for Scottish coal. Edinburgh: Napier College, 1985

175. KINCARDINE \& DEESIDE DISTRICT COUNCIL, Housing plan 1983-89. Stonehaven, 1984, 15pp

176. KIRWAN, F, "Scottish economy", Modern Studies Association Yearbook 1984, 57-62

177. KNOX, P L "Disadvantaged households and areas of deprivation microdata from the 1981 Census of Scotland", Environment \& Planning A, March 1985, 413-25

178. KNIPE, E, Gamrie: an exploration in cultural ecology - a study of maritime adaptations in a Scottish fishing village. Lanham, Maryland: University Press of America, 1984, 198pp

179. LABOUR PARTY (SCOTTISH COUNCIL), Scotland's housing crisis. Glasgow, 1984

180. L.A.M.S.A.C., Corporate management and planning in Scottish District Councils. London, 1984, 50pp

181. LIVINGSTON ACTION FOR TEENAGE HOMELESS. The LATH report: teenage homeless in Livingston. Livingston: Open Door, 1983, 74pp

182. LECLERC, R \& DRAFFAND, D, "GEAR", Town Planning Review, 55, 3 (1984) 335-51

183. LEOPOLD, J W \& BEAUMONT, P B, "Reorganisation and industrial relations in the NHS in Scotland", Scottish Government Yearbook 1985, 258-78

184. .... The development and operation of the personnel function in the NHS in Scotland. Glasgow: Glasgow University, 1984

185. LEVITT, R, The reorganised NHS (3rd edition). London: Croom Helm, 1985; see chap. 5

186. LISHMAN, J (ed), Social work in rural and urban areas. Aberdeen: Aberdeen University Dept. of Social Work, Research Highlights 9 , $1984,152 \mathrm{pp}$

187. LOCKERBIE, C, "Making waves: radio in Scotland", Cencrastus 20 (1985) 8-11

188. LORENTZEN, N. "'You can't fight for jobs and just sit there': the Lee Jeans sit-in", Fighting Closures, ed. H Levin et al (Nottingham: Spokesman, 1984, 43-62

189. LOTHIAN REGION COUNCIL, Structure Plan alteration 1984: consultative draft. Edinburgh, 1984, 69pp

190. LOTHIAN REGION COUNCIL \& EDINBURGH D.C., Rowntree Mackintosh, Edinburgh: the consequence of closure. A social audit. Edinburgh, 1985, 40pp

191. LOVE, J \& STEVENS, J, The SDA and regional policy: a resource for teachers. Glasgow: Jordanhill College, Education for the 
Industrial Society Project, $1985,19 \mathrm{pp}$

192. McARTHUR, A A, Local economic regeneration: community level effects in Clydeside. Glasgow: Glasgow University Centre for Urban and Regional Research, Discussion paper 16, 1984, 23pp

192a MACARTNEY, W J A, "Scottish Opinion Polls", Scottish Government Yearbook 1985, 317-20

193. .... "The Scottish Islands Debate", Islands of Europe, ed. W J A Macartney (Edinburgh: Unit for the Study of Government in Scotland, 1984), 7-24

194. McCRONE, D, "A commentary", Scottish Government Yearbook $1985,1-4$

195. MACDONALD, D J, The implications of the sale of council housing with special reference to Edinburgh. Diploma dissertation, Dept. of Town and Country Planning, Edinburgh College of Art/Heriot Watt University, 1983, 71+5pp

196. MACDONALD, K M K, The cost of living in rural areas of Scotland. Ph.D. thesis, Aberdeen University, 1984, 430pp (BLLD No. : D53121/85)

197. McFADDEN, J, "Glasgow; crisis and campaign", Scottish Trade Union Review 26 (1985) 33-34

198. McGRAIL, S \& PATERSON, V, For as long as it takes: Cowie miners and the strike 1984. N.p., 1985, 45pp

199. MACGREGOR, B D, Land policy in the uplands. Reading: Reading University Dept. of Land Management Working paper 3, $1984,48 \mathrm{pp}$

200. McILVANNEY, W, "Inhabiting the paradox", Radical Scotland 11 (1984) 24-27

201. MACKAY, S, Not the same cold story. Falkirk: Scottish Fuel Poverty Action Group, $1985,35 \mathrm{pp}$

202. MACKAY, T, "The oil and oil-related sector", Industry, policy and the Scottish economy, ed. Hood, N \& Young, S, 326-64

203. MACKAY CONSULTANTS et al., Incomes and earnings in the Highlands and Islands of Scotland. Inverness: HIDB, 1985, 65pp

204. McKENZIE, R P, Accessibility to employment within Greater Glasgow 1958-71. Ph.D. thesis, Aberdeen University, 1984

205. .... Transport policy and related developments within Clydeside 1945-71. Oxford; Oxford University Transport Studies Unit (TSU 270), n.d., $21 \mathrm{pp}$

206. MacKINNON, K, Scottish opinion on Gaelic. Hatfield: Hatfield Polytechnic School of Business and Social Sciences, 1981, 68pp

207. McLELLAND, C \& TURNER, J, Small firms in Glasgow, Analysis and policy recommendations. Paisley: Paisley College Dept. of Economics and Management, 1984, 47pp
208. MACLENNAN, D \& BRAILEY, M, Housing associations and rehabilitation in Scotland. Glasgow: Glasgow University Centre for Urban and Regional Research, Discussion paper 13, 1984, 38pp

209. McNAIR, B, "And now...here is the Scottish news", Radical Scotland 13 (1985) 22-24

210. McNICOLL, I H, "The impact of oil on the Shetland economy", Managerial \& Decision Economics, 1, 2 (1980)

211. .... "The pattern of oil impact on affected Scottish rural areas", Geographical Journal, 150, 2 (1984) 213-20

212. McNIE, W M, "Input-output tables for Scotland for 1979: further results", Scottish Economic Bulletin 30 (1984) 20-24

213. MANPOWER SERVICES COMMISSION, Plan for Scotland 1984 88. London, 1984, 50pp

214. .... The Shetland manpower study. Edinburgh: 1981, var.pag.

215. MARTLEW, C, Consulting business about the rates. Glasgow, Planning Exchange, Occasional Paper 14, 1984, 27pp

216. .... "Consulting non-domestic ratepayers about the rates", Local Government Policy Making, Nov. 1984, 31-35

217. .... Financing local government in Scotland: an introduction. Glasgow: Planning Exchange, Occasional Paper 11, 1984, 34pp

218. MARTLEW, C; FORRESTER, C \& BUCHANAN, G, "Activism and office: women and local government in Scotland", Local Government Studies, 11, 2 (1985) 47-65

219. MASTERSON, M P \& MASTERMAN, E M, The first community councils: the formation and election of councils throughout Scotland. Edinburgh: Scottish Office CRU, 1984, 11pp

220. MATHER, F, The analysis of employment structure. Glasgow: Glasgow University Dept. of Social and Economic Research (Inner City in Context, Clydeside Case Study, Working paper 1), 1983, 40pp

221. MATHER, F; McGREGOR, A \& ROBERTSON, I, Stability or change? Unemployment in the Glasgow connurbation 1971-81. Glasgow: Glasgow University Dept. of Social and Economic Research (Inner City in Context, Clydeside Case Study, Working paper), $1984,24 \mathrm{pp}$

222. MAXWELL, $\mathrm{K}$, Joint initiatives in housing between the public and private sectors. Glasgow: Planning Exchange, Occasional paper 10, $1983,37 \mathrm{pp}$

223. MAXWELL, S, Electronics and development: Scotland and Malaysia in the international electronics industry. Edinburgh: Scottish Education and Action for Development, 1985, 27pp

224. MEAGER, N, "Jobloss and the regions: how important is redundancy?", Regional Studies, 18,6 (1984) 459-67 (Motherwell 
case study)

225. MEILY, D E, Scottish entrepreneurs across three generations: Pittenweem. Ph.D. thesis, Rutgers University, 1984, 359pp (University Microfilms No.: 8424131)

226. MEWETT, P G, "Peripheral waywardness in the development of Scottish ethnographic studies", International Journal of Sociology and Social Policy, 3, 4 (1984) 74-81

227. MIDWINTER, A, "Rate caping in practice", New Society, 1.3.84, 336-7

228. "The politics of council housing finance", Scottish Government Yearbook 1985, 134-51

229. MIDWINTER, A; KEATING, M\& TAYLOR, P, ““Excessive and unreasonable': the politics of the Scottish hit list", Political Studies, 31,3 (1983) 394-417

230. MILLER, W, "Politics in the Scottish city 1832-1982", Perspectives of the Scottish city, ed. G Gordon, 180-211

231. MILNE, R G, "Option appraisal in the Scotish health service", Scottish Government Yearbook 1985, 279-309

232. MONKLANDS DISTRICT COUNCIL, Monklands District 1981 census: 1984 ward profiles. Coatbridge: MDC Dept. of Planning, Occasional paper 2, 1984

233. Monklands District analysis of multiple deprivation 197181.Coatbridge: MDC Dept. of Planning, Occasional paper 1, 1984, 72pp

234. Monklands District employment trends. Coatbridge: MDC Dept. of Planning, Occasional paper 3, 1985, 32pp

235. MOORE, C, Local agencies and small enterprise development in the Clydeside connurbation. Glasgow: Glasgow University Dept. of Social and Economic Research (Inner City in Context, Clydeside Case Study, Working paper 12), 1984, 56pp

236. MOORE, C \& BOOTH, S, District councils and economic regeneration in the Clydeside connurbation. Glasgow: Glasgow University Dept. of Social and Economic Research (Inner City in Context, Clydeside Case Study, Working paper 4), 1984, 41pp

238. .... Unlocking enterprise: policy innovation in Scotland. Glasgow: Strathclyde University Centre for the Study of Public Policy, Paper $137,1984,36 \mathrm{pp}$

239. .... Urban economic adjustment and regeneration: the role of the SDA. Glasgow: Glasgow University Dept. of Social and Economic Research (Inner City in Context, Clydeside Case Study, Working paper 10), 1984, 171pp

240. MOORE, C \& PITT, D C, The MSC in the Clydeside connurbation. Glasgow: Glasgow University Dept. of Social and Economic
Research (Inner City in Context, Clydeside Case Study, Working paper 7), 1984, 57pp

241. MORAY DISTRICT COUNCIL, Housing plan 1983-85. Elgin, 1984, 2 vols.

242. MORGAN, K \& SAYER, A, The international electronics industry and regional development in Britain. Brighton: Sussex University Dept. of Urban and Regional Studies, Working paper 34, 1983

243. MORRELL, J, "The prospects for employment in Scotland", Scottish Trade Union Review 26, (1985), 11-12

244. MOTHERWELL PROJECT TEAM, Motherwell: producing the goods. A second year of progress. Motherwell, 1984, 19pp

245. MOWLE, A D, The use of natural resources in the Scottish Highlands, with particular reference to the island of Mull. Ph.D. thesis, Stirling University, 1980 (BLLD No.: D38925/82)

246. MUIR, C, "Surrogate government, Tory style", Radical Scotland 14 (1985) $10-11$

247. MULHOLLAND, G, The struggle for a language: Gaelic in education. N.p. : Rank \& File, 1984

248. MURRAY, B, The Old Firm, sectarianism, sport and society in Scotland. Edinburgh, Mainstream, 1984

249. M.V.A. CONSULTANCY, Development control performance in Scotland: final report: Edinburgh: Scottish Office, 1985, 146pp

250. NAUGHTIE, J, "The Year at Westminster", Scottish Government Yearbook 1985, 23-29

251. NAYLOR, D, Local economic initiatives study, Vol. 10: SDA. Birmingham: Birmingham University Centre for Urban \& Regional Studies, 1984, 42pp

252. NITHSDALE DISTRICT COUNCIL, Annual report and financial statement Dumfries, 1984, 35pp

253. PACIONE, M, "Renewal, redevelopment and rehabilitation in Scottish cities 1945-81", Perspectives of the Scottish city. ed. G Gordon, 280-305

254. PAGE, E, Central government instruments of influence upon services delivered by local government. Ph.D. thesis, Strathclyde University, 1982 (BLLD No.: D44106/82)

255. PAYNE, D, Closure at Linwood: follow-up study of redundant workers Edinburgh: Manpower Services Commission, 1984, 34pp

256. PAYNE, G, Male occupational and social mobility in Scotland since the First World War. Ph.D. thesis, Durham University, 1983, 606pp (BLLD No.: D51697/84)

257. PEIDA, Housing demand in Scotland. London: Housing Research Foundation, 1985

258. Transport costs in peripheral areas. Edinburgh: Industry Dept. for 
Scotland (ESU Research paper 9), 1984, 99pp

259. PLANNING EXCHANGE, Lanarkshire Industrial Field Executive performance review 1983-84. Glasgow, 1984, 31pp

260. PLANNING STUDY GROUP/SHELTER, Short changed? A study of housing trends in central Edinburgh. Edinburgh, 1984, 25pp

261. POLLOCK, G J, After school: a study of employment and training experience of young adults in Scotland. London: SSRC (Report F00/23/0025), 1983, 176pp

262. PREBBLE, >, John Prebble's Scotland. London: Secker \& Warburg, 1984

263. PROCTOR, J H, "Lessons from the Scottish referendum on devolution", Journal of Constitutional and Parliamentary Studies, $16,1 / 2(1982) 1-20$

264. PROUDFOOT, B, "A perspective on the Scottish economy", Scottish Geographical Magazine, 100, 2 (1984) 96-103

265. PUNNETT, $R$ M, "Regional partisanship and the legitimacy of British governments 1868-1983", Parliamentary Affairs, 37, 2 (1984) 141-59

266. The Anglo-Celtic partisan divide. Glasgow: Strathclyde University Dept. of Government (Papers on Government \& Politics 16), 1983

267. .... "Two nations? Regional partisanship 1968-83", Scottish Government Yearbook 1985, 30-52

268. RADICAL SCOTLAND, "79 Group" where are they now?", Radical Scotland, June/July 1983, 7-9

269. .... "Radicalising Labour's Green Paper", Radical Scotland 12 (1984) 9-11

270. .... "The forward march of vox pop". Radical Scotland 12 (1984) 6-8

271. RANDALL, J N, "Economic trends and support to economic activity in rural Scotland", Scottish Economic Bulletin 31 (1985) 1020

272. RANK AND FILE, Women and the E.I.S. N.p. n.d. (1983), 20pp

273. RAWLING, E, Energy and the environment. Harlow: Longman, 1983, 29pp

274. REID, M, "Changing Scotland", Scotsman, 28-31.5.1985

275. RENFREW DISTRICT COUNCIL, Annual report and financial statement 1983/4. Paisley, 1985, 51pp

276. RICH, D C, "The SDA and the industrial regeneration of Scotland", Geographical Review, 73 (1983) 271-86

277. ROBERTSON, J G, The environmental impact of North Sea oil related developments on Scotland. Portree: Habitat Scotland, 1984, $88 \mathrm{pp}$

278. ROSE, R, National price: cross-national surveys. Glasgow: Strathclyde University Centre for the Study of Public Policy, Paper
$136,1984,28 \mathrm{pp}$

279. ROWAN-ROBINSON, J et al, Community councils and public participation: the Grampian Rural Area Structure Plan. Gloucester: Gloucestershire College of Arts and Technology Dept. of Town \& Country Planning, 1984, 47pp

280. ROY, K, The Scottish companion 1985. Ayr: Carrick Publications, 1985, 191pp

281. RUDOLPH, J R \& THOMPSON, R T, "Ethnonational movements and the policy process: accommodating nationalist demands in the developed world", Comparative Politics, 17, 3 (1985) 291-311

282. RUTHERFORD, A, Community councils in Scotland: their first five years. Glasgow: Strathclyde University Dept. of Government (Papers in Government and Politics 36), 1984

283. SAUNDERS, $P$, The 'regional state': a review of the literature and agenda for research. Brighton: Sussex University Dept. of Urban and Regional Studies, Working paper 35, 1983, 82pp

284. SCOTTISH COMMISSION FOR RACIAL EQUALITY, Annual report 1983. Glasgow, 1984

285. SCOTTISH COUNCIL FOR THE SINGLE HOMELESS, Opening doors: allocating houses to single people. Edinburgh, 1984, 40pp

286. SCOTTISH DEVELOPMENT AGENCY, Accounts...for the year ended 31.3.84. London: House of Commons paper 489, 1984, 27pp

287. .... Annual report 84. Glasgow, 1985, 90+13pp

288. .... Labour performance of US plants in Scotland. Glasgow, 1984, $26 \mathrm{pp}$

289. .... Local enterprise grants for urban projects (LEG-UP). Glasgow 1984, 15pp

290. .... North American factories manufacturing in Scotland. Glasgow, $1984,5 \mathrm{pp}$

291. .... Overseas and European companies manufacturing in Scotland. Glasgow, 1984, 3pp

292. .... The Scottish electronics subcontracting components supply industries. Glasgow, n.d., 28pp

293. SCOTTISH DEVELOPMENT DEPARTMENT, Applications to buy public sector houses 1983. Edinburgh: SDD (Statistical Bulletin HSIU 11), 1985, 6pp

294. .... Competition in the provision of local authority services. Consultation paper. Edinburgh: Scottish Office, 1985, 13pp

295. ... Condensation in housing: a report on local authority returns, survey methods and remedial measures. Edinburgh, 1984, 55pp

296. .... Public sector rents 1983-84. Edinburgh: SDD (Statistical Bulletin HSIU 7), 1984, 6pp 
297. .... Sales of public sector houses. Edinburgh: SDD (Statistical Bulletin HSIU 3), 1984, 8pp

298. .... Submission to the Committee of Enquiry into the conduct of local authority business - the use of local authority discretionary standing powers to engage in political campaigning and publicity. Edinburgh, $1985,46 \mathrm{pp}$

299. SCOTTISH EDUCATION DEPARTMENT, The future of school councils in Scotland: a consultative paper. Edinburgh, 1984, var.pag.

300. SCOTTISH FEDERATION OF HOUSING ASSOCIATIONS, Miles better, miles to go. The story of Glasgow's housing associations. Glasgow, 1984, 4 booklets

301. SCOTTISH HEALTH SERVICE PLANNING COUNCIL, Report for 1983. Edinburgh: HMSO, 1984, 17pp

302. SCOTTISH HOME \& HEALTH DEPARTMENT, Health in Scotland 1983. Edinburgh, 1984, 79pp

303. SCOTTISH INFORMATION OFFICE, Industry in Scotland. Edinburgh: SIO (Factsheet 17), 1985, 34pp

304. .... Planning for development. Edinburgh: SIO (Factsheet 5), 1985 , $10 \mathrm{pp}$

305. .... The economy of Scotland. Edinburgh: SIO (Factsheet 10), 1985, $27 \mathrm{pp}$

306. .... The Scottish Office. Edinburgh: SIO (Factsheet 20), 1985, 15pp

307. SCOTTISH OFFICE, A ¿ «ss to local authority accounts: consultative paper. Edinburgh, 1984, 7pp

308. .... Public expenditure to 1987-88. A commentary on the Scotland programme. Edinburgh, 1985, 126pp

309. .... Scottish local government financial statistics. Edinburgh, 1985, $27 \mathrm{pp}$

310. SCOTTISH SPECIAL HOUSING ASSOCIATION, $A$ mirror of Scottish housing: the history and development of the SSHA. Edinburgh, 1983, 40pp

311. Annual report for the year ended 31.3.84. Edinburgh, 1984

312. SCOTTISH TRADES UNION CONGRESS, 87 th annual report. Glasgow, 1984, 792pp

313. SCOTTISH TRANSPORT STUDIES GROUP, Annual report for 1984. Glasgow: Glasgow University Centre for Urban and Regional Research, 1984, 30pp

314. SCRIMGEOUR, P A A, "Employment in industrial R\&D in Scotland and the UK", Scottish Economic Bulletin 29 (1984) 9-10

315. SECRETARY OF STATE FOR SCOTLAND, Housing support grant (Scotland) order 1985: report. London: House of Commons paper $135,1985,10 \mathrm{pp}$

316. .... Housing support grant (Scotland) variation order 1985: report.
London: House of Commons paper 136, 1985, 11pp

317. .... Rates support grant (Scotland) (No.2) order 1984: report. London: House of Commons paper 581, 1984, 7pp

318. .... Rates support grant (Scotland) order 1985: report. London: House of Commons paper 146, 1985, 31pp

319. .... Rates support grant (Scotland) (No.2) order 1985: report. London: House of Commons paper 264, 1985, 4pp

320. SELMAN, P G, Public participation in local planning: theory and case study of Gorgie-Dalry. M.Phil. thesis, Edinburgh University, 1981

321. SEWEL, J; TWINE, F \& WILLIAMS, N, "The sale of council houses: some empirical evidence", Urban Studies, 21, 4 (1984) 43950

322. SHELTER, Briefing note for debate on Housing Support Grant (Scotland) Order 1985. Edinburgh, 1985, 7pp+tables

323. .... Homeless young people in Glasgow. 1984, 29pp

324. .... Housing in Scotland. Edinburgh, 1984, 49pp

325. .... No place like home. Edinburgh, 1984, 52pp

326. SHETLAND ISLANDS COUNCIL, Annual financial report 1982 83. Lerwick, 1984, 62pp

327. .... Housing plan 1984-98. Lerwick, 1983, 67pp

328. SHUCKSMITH, M, Scotland's rural housing: a forgotten problem. Perth: Rural Forum, 1984, 48pp

329. SHUCKSMITH, M \& LLOYD, G, "Rural planning in Scotland: a critique", Countryside Planning Yearbook. 1983, 103-28

330. SIMM, D, Glasgow's special housing initiatives: ways of dealing with difficult to let estates. Glasgow: Glasgow DC Housing Dept., Research Memorandum 3, 1984

331. SIM, D \& BROOKE, J, Clearance in the 1980's: the experience of Barlanark. Glasgow: Glasgow DC Housing Dept., Research Memorandum 4, 1984, 30pp

332. SIMPSON, D R F \& McGilvRAY, J M, Development and application of a multi-sectoral model of the Scottish economy. London: SSRC (Report HR 6222/1), 1982, 402pp

333. SINCLAIR, A Sewing it up. Edinburgh: Scottish Education and Action for Development, 1984, 30pp (Coats Patons)

334. SMALL, D B \& SMITH, L D, "The food, drink and tobacco sector", Industry, policy and the Scottish economy, ed. Hood, N\& Young, S, 174-212

335. SMART, H W, Criticism and corporate rationality: Strathclyde Region Council deprivation policy 1975-80. Ph.D. thesis, Aberdeen, $1984,415 \mathrm{pp}$

336. SMITH, H D, "The role of the sea in the political geography of 
Scotland", Scottish Geographical Magazine, 100, 3 (1984) 138-50

337. SMITH, R \& WANNOP, U (eds), Strategic planning in action: the impact of the Clyde Valley Plan 1946-82. Aldershot: Gower, 1985, 288pp

338. SMITH, J, "The forward march of Labour halted?", Radical Scotland 13 (1985) 7-10

339. STASSINOPOULOU-HOLLOWAY, O, Housing and employment in the Borders Region. Edinburgh, 1983, 330pp

340. STEEL, B S, Ethnoregionalist threat to supranational integration: impact on British attitudes toward the European Communities. Ph.D. thesis, Washington State University, 1984, 271pp (University Microfilm No. 8423023)

341. STIRLING DISTRICT COUNCIL, Homelessness 1978-84: the implementation of the Housing (Homeless Persons) Act 1977. Stirling, 1984, 43pp

342. .... Housing plan 1984/89: task group report. Stirling, 1983, 104pp

343. .... Housing plan 1985/90. Stirling, 1984

344. STRATHCLYDE HOUSING LIAISON GROUP, The need for increased investment in council housing in Strathclyde. Glasgow, 1984

345. STRATHCLYDE REGION COUNCIL, 1982 base projections to 1989: population, households, housing: main report. Glasgow, 1984, $7 \mathrm{pp}$

346. .... 1983 base population, household and housing projections: main report. Glasgow, 1984, 36pp

347. ... 1983 base population, household and housing projections: technical notes. Glasgow, 1984

348. .... Strathclyde Structure Plan 1981: ecological guidelines. Glasgow, 1981, 62pp

349. ... Strathclyde Structure Plan: monitoring report 1983. Glasgow, 1983, 58pp

350. .... Strathclyde Structure Plan: Monitoring report 1984. Glasgow, 1985, 85pp

351. ... Strathclyde Structure Plan: written statement 1984 (second review $s$ and alteration). Glasgow, 1985, 126pp

352. .... Strathclyde Structure Plan: written statement 1984 (second review and alteration). Consultation report. Glasgow, 1985, 121pp

353. .... Trends in industrial performance. Glasgow: SRC Chief Executive's Dept., 1984, 12pp

354. TAIT, B, "Doubts and fears about socialism", Radical Scotland, June/July 1983, 14-15

355. TAIT, K S, Corporation house sales in Livingston New Town. M.A. dissertation, Edinburgh University Dept. of Politics, 1985, var.pag.
356. TAYSIDE REGION COUNCIL, Annual report and accounts for the year ended 31.3.84. Dundee, 1984, 58pp

357. .... Transport policies and programme 1984-89. Dundee, 1984, 202pp

358. THOMASON, E, "Handling Shetland's money", New Shetlander 151 (1985) 11-12

359. THOMPSON, W, "From Shetland to the Borders", Scottish Marxist 29 (1984) $14-15$

360. THOMSON, D, Why Gaelic matters. Edinburgh:Saltire Society, 1985

361. THOMSON, S, An evaluation of local plan production and performance. Edinburgh: SDD, 1984, 61pp

362. TIRYAKIAN, E A \& ROGOWSKI, R (EDS), New nationalisms of the developed West. London: Allen \& Unwin, 1985, 350pp

363. TUCKER, S, Local authority annual reports in Scotiand. Glasgow: Scottish Consumer Council, 1984, 37pp

364. TWINE, F, "Council house sales in Aberdeen", Housing in Scotland, ed. D Alexander

365. ... Low pay in Scotland. London: Low Pay Unit, 1983

366. TWINE, F \& WILLIAMS, N J, "Social segregation in public sector housing", Transactions, Institute of British Geographers, 8, 3 (1983) 253-66

367. VAN DE VLIET, A, "Scotland's painful rebirth", Management Today, Jan. 1984, 86ff

368. VAN MECHELEN, D P, Growth of third party support in Britain: a comparative study of the electoral base of the Liberal and Scottish National Party's succeses during the 1970's. Ph.D. thesis, London School of Economics, 1983

369. WALKER, F M, Song of the Clyde: a history of Clyde shipbuilding. Cambridge: Patrick Stephens, 1984

370. WANNOP, U, "The evolution and roles of the SDA", Town Planning Review, 55, 3 (1984) 313-21

371. WATSON, R, "The Scotish political juncture", Cencrastus 20 (1985) 15-18

372. WESTERN ISLES ISLANDS COUNTIL, Transport policies and programme 1983-88. Stornoway, n.d., 47pp

373. WEST LOTHIAN DISTRICT COUNCIL, Fourth housing plan and programme 1984/5-1989/90. Linlithgow, 1985, 65pp

374. WEST OF SCOTLAND POLITICS OF HEALTH GROUP, Glasgow: health of a city. Glasgow, $1984,37 \mathrm{pp}$

375. WICKHAM-JONES, M, Breathing life into Ceasar? The work of the Church and Nation Committee. M.A. dissertation, Edinburgh University Dept. of Politics, 1985, 102pp 
376. WILliAMSON, E A, Survey of the Shetland media. Lerwick: Shetland Council of Social Service, 1983, 51pp

\section{INDEX TO BIBLIOGRAPHY}

377. WILSON, G, "Nationalism for nationalists", Radical Scotland June/ July $1983,16-17$

378. "The parliamentary role of the SNP", Parliamentarian, 66, 1 (1985) 20-21

379. YOUNG, A, "Quality, not quantity matters", Scottish Business Insider. 2, 5 (1985), 9-10

380. "Regional aid: making the best of a new regine", Scottish Business Insider, 2, 3 1985) 19-20

381. YOUNG, J D, Women and popular struggles: a history of the Scottish and English working-class women 1500-1984. Edinburgh: Mainstream, 1985, 219pp

382. YOUNG, S, "The foreign-owned manufacturing sector", Industry, policy and the Scottish economy, ed. Hood, N \& Young, S, 93-127

383. YOUNG, S \& HOOD, N, "Industrial policy and the Scottish economy", Industry, policy and the Scottish economy, ed. Hood, N \& Young, S, 28-56

384. YOUNG, S \& REEVES, A, "The engineering and metals sector", Industry, policy and the Scottish economy, ed. Hood, N \& Young, S, 128-73

385. YOUNGER, G, Text of...the Andrew John Williamson Memorial Lecture ...June 1, 1984. Edinburgh: Scotish Information Office (Press release 608/84), 1984, 9pp

Aberdeen: $37,49,121,122,152,321,364$

Bibliographies, research guides: $6,36,106,140,313$ Borders Region: 25, 26, 339

Catholic Church: 34

Churches: 34

Church of Scotland: 83, 375

Class, stratification, class consciousness: 366

Closures: see under economy

Clydeside: 192, 205, 220, 235, 236, 240, 337, 369

Clyde Valley Plan: 337

Committee on Scottish Affairs: see Select Committee

'Community': 40, 178

Community Councils: $219,279,282$

Community politics: $125,201,225$

Crofting: 65

Culture and politics: 28, 32, 200

'Current affairs': See Politics, current commentary:

Demography: $111,232,345-47$

Deprivation, poverty: (see also rural deprivation) $73,168,177,201,233,335,365,374$

Devolution, general, concept of: 99

Devolution, as political issue: $1,41,42,270$

Devolution and:

Campaign for a Scottish Assembly: 41, 42

Labour Party: 86, 269

Devolution referendum: 30,263

Dumfries \& Galloway: 75-77

Economy, general, 132, 133, 147, 176, 212. 264, 305, 332, 386 banking, finance: 15

coal: $131,173,174$

closures: $119,123,190,255$

electronics: $96,120,126,223,242,292$

farming, fishing: 43

foreign investment, ownership: 96, 120, 155, 188, 288, 290, 291, 379 .

382 
industry: $17,18,48,61,95,96,115,119,134,154,303,334,367,369$, 384

local economics studies: $25,72,94,103,192,220,224,244,348-53$ policy, strategy: $9,16,72,96,117,127-29,148,192,207,238,271$, $276,289,304,337$

regional policy: $8,12,95,126,147,190,224,242,337,380,383$

research and development: $96,150,314$

service sector: 67

unemployment, employment: 7, 39, 67, 86, 100, 105, 108, 134, 156, $213,221,224,234,243,259,261,339$

wage levels: 203,365

Edinburgh: 50, 79, 85, 118, 190, 195, 260, 320

Education: 109, 213, 272, 354

Elections, General: 31

European: 22

local: $23,24,62,163,171$

voting behaviour: $28,32,230,265-7,340,368$

EEC: $167,171,340$

Fife Region: 90-94

Gaelic: $206,247,360$

Glasgow: 14, 19,54, 62, 101-105, 149, 158, 197, 204, 207, 220, 221, 300, 323 , $330,331,374$

Glasgow East Area Renewal (GEAR): 54, 69, 70, 182, 239

Grampian Region: 16, 110-113, 279

Gypsies: 113

Health, NHS: $88,114,151,183,184,185,231,301,302,374$

Health Councils: 13

Highlands: 5, 10, 106, 139, 160, 199, 203, 245

HIDB: $5,56,58,137-40,271$

Housing, general: $3,141,179,253,257,260,324,339$

associations: $149,208,300,310,311$

dampness: 295

finance: $159,228,315,316,322,345$

homelessness: $19,181,285,323,325,341$

plans, reviews: $53,74,78,87 \mathrm{a}, 92,101,104,175,241,327,342,343$,

373

private sector: 11,222

public sector: $4,46,84,157,222,296,330,331,345,366$

rural: 328

sale of council houses: $4,11,85,142,195,293,297,321,355,364$
SSHA: $143,310,311$

tenant organisations, participation: 125

women and: 27

Housing Associations: see Housing

Identity, national: $28,32,99,278$

Industrial relations: $37,183,184,188$

Labour history, labour movement: 381

Labour Party: 31, 179, 338

Land: $10,199,274$

Left in Scotland: 79, 354

Livingstone: $136,181,355$

Local government, general: $66,89,124,236,363$

accountability: 307,363

administration \& management: 180,335

central-local relations: 165, 197, 227-229, 254, 298

councillors: 218

finance, rates, spending (cuts): 14, 33, 44, 55, 59, 215, 216, 217, 227,

$229,254,298,307,309,317-319$

privatisation of services: 294

reform: 1,66

Local politics: 230

Manpower Services Commission: 213, 240

Media, and Scotland:

newspapers: 52, 209

radio, 187

Migration: $108,160,161$

Miners, miners strike: $68,198,209$

Motherwell: 224, 244

Nationalism, general: $28,29,32,36,130,278,340,368$ comparative studies: $29,82,166,281,362$ and Left: 82

New Towns: $134,157,170$

NHS: see Health, NHS

Oil, effects of: economic: $20,61,115,121,131,202,210,211$ social, environmental: $40,116,152,211,273,277$ and local government: 116,122

Opinion poll data and analysis: $98,193 \mathrm{a}, 270$

Orkney: 193 


\section{Scottish Government Yearbook 1986}

Parliament: 246, 250, 381

Planning general: 97, 118, 135, 361

administration: $51,60,114,162,249$

housing plans: see Housing, plans

local plans: 38,189

participation in: $153,279,320$

rural: 329

transport: $77,112,357,372$

Policy making: 114, 143, 231

Political culture: 248

Political system: 172, 230, 283

Politics, current commentary: $194,359,371$

Protestantism, militant: 35

Public expenditure: 57, 308

Race, racism: 284

Religion: 35,248

Rural deprivation: 71, 186, 196, 258, 328

Rural development (see also Highlands): 16, 71, 106, 245, 271

School councils: 299

Scotland general: $262,280,336$

and Third World: 333

as part of the United Kingdom: 265-7, 340

Scottish Daily News: 52

Scottish Development Agency:9, 58, 117, 148, 171, 190, 238, 239, 251, 259, $276,286,287,370$

Scottish National Party, description, analysis: $63,80,340,368,377,378$ 79 Group: 268

Scottish Office: $109,144,145,169,250,306,385$

Scottish T.U.C.: $172 \mathrm{a}, 312$

Secretary of State for Scotland: 250, 385

Select Committee on Scottish Affairs: 56, 246

Shetland: $20,193,210,214,358,376$

Social Democratic Party: 64

Social security: 98

Social mobility: 47,256

Social services: 186

Sociology of Scotland: 178,366

Stirling: $341-43$

Strathclyde Region: $325,335,344,345-53$
Tayside Region: 356,357

Trade unions: 37

Transport, roads: $204,205,313$

Underdevelopment of Scotland, dependency: 121, 130, 133, 223, 242, 292

Urban politics: 230

Urban problems: general: 39, 107, 164, 168, 186

Easterhouse: 45, 129

Greenock: 125

Urban regeneration: $54,158,164,192,235,236,239,253$ (see also GEAR)

Western Isles: 16, 40, 193, 226, 372

Women: $27,47,68,83,135,188,198,218,272,381$ 